\title{
Climate Change Risk Management in Transnational River Basins: The Rhine
}

\author{
Saskia C. van Pelt • Rob J. Swart
}

Received: 23 June 2010 / Accepted: 25 July 2011 /

Published online: 25 August 2011

(C) The Author(s) 2011. This article is published with open access at Springerlink.com

\begin{abstract}
Climate change is likely to have an impact on the discharge of the European river Rhine. To base adaptation strategies, to deal with these changing river discharges, on the best scientific and technical knowledge, it is important to understand potential climate impacts, as well as the capacity of social and natural systems to adapt. Both are characterized by large uncertainties, at different scales, that range from individual to local to regional to international. This review paper addresses three challenges. Dealing with climate change uncertainties for the development of adaptation strategies is the first challenge. We find that communication of uncertainties in support of river basin adaptation planning generally only covers a small part of the spectrum of prevailing uncertainties, e.g. by using only one model or scenario and one approach to deal with the uncertainties. The second challenge identified in this paper is to overcome the current mismatch of supply of scientific knowledge by scientists and the demand by policy makers. Early experiences with 'assess-risk-of-policy' approaches analysis of options, starting from the resilience of development plans, suggests that this approach better responds to policy makers' needs. The third challenge is to adequately capture the transnational character of the Rhine river basin in research and policy. Development and implementation of adaptation options derived from integrated analysis at the full river basin level, rather than within the boundaries of the riparian countries, can offer new opportunities, but will also meet many practical challenges.
\end{abstract}

Keywords Climate change adaptation · Multi-level governance $\cdot$ River Rhine · Science-policy interface $\cdot$ Climate change uncertainties

Presented at 2009 Amsterdam Conference on the Human Dimensions of Global Environmental Change

S. C. van Pelt $(\square)$

Earth System Science and Climate Change Group, Wageningen University and Research Centre,

Wageningen, the Netherlands

e-mail: saskia.vanpelt@wur.nl

R. J. Swart

Alterra, Wageningen University and Research Centre, Wageningen, the Netherlands 


\section{Introduction}

\subsection{The Problem: Too Much Water, or Too Little}

Climate change is one of the major challenges society will face during this century. Temperatures are projected to increase up to $6.4^{\circ} \mathrm{C}$ by 2100 , which is expected to result in major changes in the atmosphere's energy balance and the hydrological cycle (IPCC 2007). Especially extreme events that result from these changes will impact human society, for example through heat waves, droughts and floods (Beniston et al. 2007). A recent example of the effect of climate extremes on water resources was in the summer of 2003, when a heat wave afflicted Europe. The result of this heat wave, with summer (June, July, August) temperatures exceeding the 1961-1990 mean by $3^{\circ} \mathrm{C}$ (Schär et al. 2004), was not only a large number of casualties and other heat-related impacts, but also water resources were seriously affected. Large losses in crop yield and extremely low river discharges were reported in large parts of Europe. In Cologne, the river Rhine showed the lowest discharge since 1930 (Fink et al. 2004). The water level in the Rhine in the Netherlands and Germany reached critically low levels for power plants (Jacob and van den Hurk 2009; Fink et al. 2004). A year earlier, in 2002, the opposite was happening when a large region, stretching from Germany and Austria to Romania and Russia, experienced severe floods. Although these events cannot directly or conclusively be attributed to climate change (Jacob and van den Hurk 2009), the IPCC's Fourth Assessment Report (2007) concluded that in the future anthropogenic climate change 'likely' to 'very likely' leads to increases in intensity and frequency of temperature and precipitation extremes. These phenomena are not constrained by watersheds or national boundaries, they can afflict large areas and many countries simultaneously and during these events conflicts between competing resource requirements, like drinking water, water for irrigation or cooling water for power plants, can be most intense. As a consequence, the urgency of a better understanding of risks of extreme hydrological events is increasing, both from a scientific and political perspective (Lehner et al. 2006). In this review paper, we focus on three challenges of climate change adaptation for transnational river basin management using the Rhine river basin as a case study area: dealing with climate change uncertainties, addressing science-policy interaction problems, and capturing the transnational character of adaptation in transnational river basins.

\subsection{Climate Change Adaptation in International River Basins Under Uncertainty}

The development of adaptation strategies has started just recently in river basins such as the Rhine, after the emergence of climate change and associated impacts as a reason for concern. This paper reviews the current situation and identifies key questions that should be addressed to facilitate the development of adaptation strategies. Formulating adaptation strategies poses a great challenge for both the scientific community and policymakers, particularly because of the incomplete understanding of natural and societal systems and the many associated uncertainties (Dessai and van der Sluis 2007; Prudhomme and Davies 2009). Dealing with uncertainties is not new to policy makers in the Rhine basin, because they have been dealing with water related uncertainties for decades. Floods and droughts are extreme events and it is hard to predict when they are going to happen and what the consequences will be. Policy makers and scientists have tried to estimate the probability of especially flooding on the basis of historical data and use these data to set the standards for safety levels. Adaptation strategies for river basins are necessarily not only based on historical data, as the magnitude and ubiquity of the projected hydroclimatic climate change requires going beyond stationarity as a central default 
assumption in water-resource risk management and planning (Milly et al. 2008). Adaptation strategies should therefore also be based on scenario analyses using climate impact models. These impact models, for example hydrological models, use temperature or precipitation simulations of global or regional climate models as input. In climate simulations used for the development of adaptation strategies, uncertainties at various levels of the assessment accumulate. The uncertainties are associated with future greenhouse emissions, the response of the climate system and with the spatial and temporal distributions of impacts (Dessai and van der Sluis 2007). Policy makers and scientists need to deal with uncertainties in such a way that robust 'low-regret' or 'win-win' strategies can be formulated. When a strategy is robust, it performs relatively well, compared to alternatives, across a wide range of plausible futures (Lempert et al. 2006). In addition, also criteria like e.g. flexibility, costs and social acceptance are relevant for the selection and design of adaptation actions (Aerts and Droogers 2009; Lopez et al. 2009). Formulating robust strategies will only be possible if knowledge is effectively shared between the scientific climate community and policymakers at the many relevant governance levels, from local to international. Insufficient communication between scientists and policymakers and inadequate policy relevant information could lead to delay and inaction or to inefficient adaptation strategies (Alkhaled et al. 2007). Effective integration of science and decision making requires a tight coupling among research, communication and use of scientific output (Pielke Jr et al. 2000). Risk management of climate change does not only pose a challenge for local policy makers, it is an issue relevant also at higher levels of governance: regional, national and in case of the Rhine basin also international. The Rhine flows through several countries and many governmental authorities with different territorial boundaries are involved. Climate adaptation strategies are therefore of international importance and one may expect that really effective risk management would benefit from cooperation between the riparian countries. Sadoff and Grey (2002) show in their paper also other benefits from cooperation between riparian countries, ranging from benefits to and from the river, like management of ecosystems and increased food production, to reduction of costs and eventually cooperation beyond river basin management issues alone. This paper will focus on the opportunities regarding climate risk management in the Rhine basin that could be provided by international cooperation, but it is important to be aware of other benefits.

\subsection{Objectives of This Review}

In a transnational river basin, effective risk management requires a good match between information needs of policymakers and knowledge availability from the scientific community, robust management of uncertainties and transboundary cooperation. The objective of this paper is to take stock of current policy and science developments in the Rhine river basin and to address the following three questions:

- How are climate change uncertainties dealt with?

- How does a (mis) match between information needs and knowledge availability across different geographical and administrative scales stimulate or constrain effective adaptation policy development?

- What is the effect of (lack of) transboundary cooperation on climate change adaptation management?

Addressing these questions, priority research gaps to improve robust adaptation policy development in transnational river basins can be identified. This paper is based on a yet rather limited knowledge base. By structuring the problem of transnational climate change adaptation in a multilevel context we can give preliminary answers to these questions that 
may guide future research and policy development. We have based our findings on the review of available papers and documents and various informal contacts with particularly Dutch policy advisors and policy makers. The following sections will elaborate on the above questions, illustrated for the Rhine basin case study. Section 2 summarizes the framework and approach used for structuring this paper. Section 3 summarizes the scientific climate change knowledge base, focusing on spatial and temporal scales of climate models and introducing the uncertainties that are involved with climate change modelling. Section 4 addresses the (mis) match between information needs and knowledge availability. Section 5 examines the challenges that arise from transboundary cooperation in the Rhine basin. Section 6 discusses a Dutch case study and the final section presents preliminary responses to the above questions and identifies research gaps.

\section{Approach}

\subsection{A Framework for Analysis}

Figure 1 is used as an organizing structure for our paper. It shows interactions of the governance processes at different levels and the natural science processes at different spatial scales. The left hand side of the figure represents the multi-level governance processes which, together with the scientific knowledge, result in the formation of adaptation strategies and measures. Multi-level governance in this context means that policy is determined by processes on several different territorial and administrative scales, varying from local, regional, national to European or even global (Marks and Hooghe 2004; Pierre 2000). The focus of this paper is on the national and European level, but some of the conclusions can also be valid for the local and regional governance levels. The right hand side of the figure represents natural science, where scientists simulate the impacts of climate change, usually with computer models. Socio-economic scenarios, such as those developed by the IPCC, are used to create emission scenarios, which serve as input for global climate models (GCMs). GCM outputs are downscaled, e.g. using regional climate models (RCMs) or statistical downscaling methods. In most cases, bias correction is required to improve the results. Impact models are then used to simulate the local impacts of climate change on

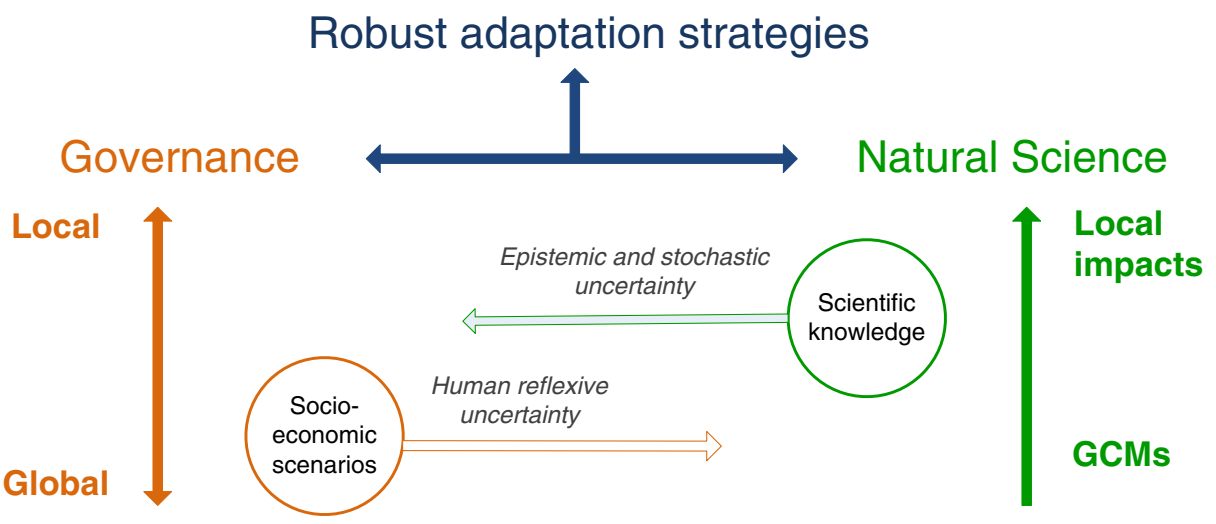

Fig. 1 Interactions of science and governance at different scales for knowledge of robust adaptation strategies 
social- and biophysical systems, for example hydrological models that simulate discharge for river basins.

Adaptation strategies are partly based on the results of these models. When, for example, the result of the modelling on the right hand side of the figure indicates that it is likely that river discharges will increase, water managers can increase the height of dikes, which is in this case an adaptation strategy Another example is if water levels are projected to decrease, and measures are required to adapt inland shipping practices. However, adaptation choices will not only depend on the modelling result, but also on other factors, like costs, impacts on environment, public response and acceptance, technical feasibility and demographic and water use changes (Lopez et al. 2009). These factors will be part of the negotiations in the governance process. Water managers need information about the duration, magnitude, frequency and timing of future drought and flood relative to past and recent events, but also about how adaptable the natural and human systems are to these changes (Lopez et al. 2009; Palmer et al. 2009). The development of adaptation strategies in the Rhine basin that are robust across a range of possible future changes can be achieved by a good match between the supply and demand of scientific knowledge. This process is displayed in the centre of Fig. 1. Supply and demand for information emerge from complex networks of individuals and institutions with diverse incentives, capabilities, roles and culture. In this paper we conceptualize science, in this case results of climate and impact models, as 'supplier' of knowledge and information. The policymakers who seek to apply knowledge and information to achieve specific goals, have a 'demand'. For this paper, we focus on the development of climate adaptation strategies as a policy goal.

\subsection{Types of Uncertainties}

Three types of uncertainties can be distinguished that determine the uncertainty range of future climate and impact projections: (a) incomplete knowledge (epistemic uncertainty), (b) unknowable factors (stochastic uncertainty, e.g. intrinsic variability in the climate system) and (c) human reflexivity (Dessai and Hulme 2003). Epistemic and stochastic uncertainty are part of the scientific climate model output. The third type of uncertainty, human reflexivity, is introduced by the social system. Humans can reflect critically on information and change their behaviour. Society is likely to act upon scientists' projections that climate will change (Dessai and Hulme 2003). The behaviour of society influences the climate and impact projections because the social-economic and associated emission scenarios change as a function of the policy responses: when scientists project that the climate will change due to anthropogenic greenhouse gas emissions it is likely that mitigation measures will be taken. These measures influence the climate scenarios that have been developed and in that sense influence the range of climate change impacts that are projected. Policy makers at different levels are confronted with the scientific output of climate models. At higher administrative levels this knowledge is mostly used to support the formulation of rather broad adaptation strategies, like the Dutch and German National Adaptation Strategies, while at local levels it provides input into the design of more concrete adaptation measures. Concrete adaptation measures can be, for example, building houses that are resistant to flooding or increasing the height of dikes, or changing rules for spatial planning in flood-prone areas. This process requires adequate 'vertical interaction' between different administrative levels in the governance system and 'horizontal interaction' with the scientific community at each level.

Whilst Dessai and Hulme's (2003) uncertainty types are formulated from a scientist's perspective, for a policy maker, who has to use information about climate change in order to 
formulate adaptation measures, climate change can be associated with conditions of deep uncertainty. By deep uncertainty we mean both scientific and social factors that are difficult to accurately define and quantify (Kandlikar et al. 2005). Deep uncertainty is present at all levels of the uncertainty typology of Dessai and Hulme (2003) as in every level uncertainties exist that cannot be quantified or accurately defined. The most deep uncertainty exists in the human reflexive uncertainty, as this is not quantifiable other than in a hypothetical scenario context. Lempert et al. (2004) uses deep uncertainty to refer to conditions that policymakers do not know, or do not agree on regarding (1) the appropriate model to describe interactions among a system's variable, (2) the probability distributions to represent uncertainty about key parameters in the models, or (3) how to value the desirability of alternative outcomes. When uncertainty is such an important variable, it makes sense for policymakers and scientists to identify strategies that are robust, i.e. perform well over a wide range of different futures. Ideally these strategies would also be 'win-win' or no-regret, but in practice, for strategies that mainly address climate change impacts there can be opportunity costs, trade-offs, or externalities associated with adaptation actions so it is better to refer to such interventions as 'low regret' (Wilby and Dessai 2010). In many cases however, climate change is just one of many other factors that determine strategies or investment decisions, and in those cases win-win or no regret options may be identified. In our review we first focus on the right hand side of Fig. 1, then the left hand side. The danger of examining both sides separately is that interactions within the whole system are missed and the complete picture is lost. For the sake of simplicity of this review paper we decided to deal with the two sides subsequently and in the final section to focus on the whole integrated system.

\subsection{Dealing with Uncertainties: 'Predict-Then-Act' Approach Versus 'Assess-Risk-Of-Policy' Approach}

As climate change is a very complex problem, policy makers turn to scientists for specific advice. Because of the large uncertainty of climate change projections, there is an increasing consensus that it is important to communicate and deal with this uncertainty. There is less consensus, however, on the best practices for doing this (Patt 2009). Different academic disciplines offer diverging advice on this subject. For this review, we distinguish between two fundamentally different approaches (Dessai and Hulme 2004).

The first approach is the 'predict-then-act' approach sometimes also referred to as the top-down approach, which is shown in the left hand side of Fig. 2. It focuses on downscaled global climate change scenarios and it is strong in dealing with statistical uncertainty (Dessai and van der Sluis 2007). For this approach one or more climate scenarios are used as starting point for an impact assessment. The goal is then to derive an optimum adaptation strategy, based on the results of the impact assessment, seeking to find a solution that performs best contingent to a particular view (Lempert and Collins 2007). In Fig. 1 the 'predict-then-act' approach has a focus on climate change scenarios and climate model outcomes from the right hand side. Future developments are projected as accurately as possible and research supporting this approach aims at decreasing uncertainties. The approach is widely used and accepted. The IPCC and most national and region adaptation assessments in Europe, for example, take this approach, starting with impact assessments on the basis of downscaled climate modelling results (Wilby et al. 2009). The second approach called the 'assess-risk-of-policy' approach or sometimes the bottom-up approach, is shown in the right hand side of Fig. 2. It does not take climate projections as the starting point, but the vulnerability of the system itself, its development ambitions and its resilience. 
Fig. 2 Two approaches for dealing with uncertainty adopted from Dessai et al. (2009)
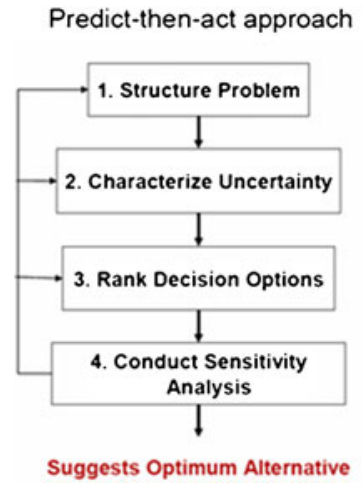

Assess-risk-of-policy framework

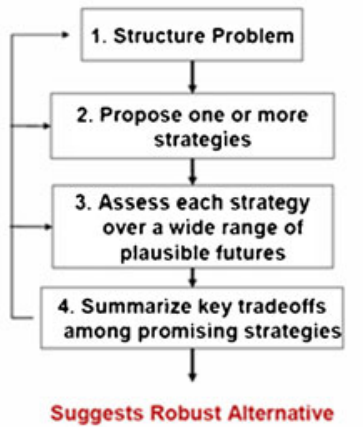

Resilience can be defined as the ability of the system to absorb disturbances (Aerts and Droogers 2009). This approach takes into account a broader set of issues from the start, and is stronger in coping with ignorance and surprises. It seeks adaptation strategies that can make the system less vulnerable to uncertain climate change impacts and unpredictable variations in the climate system (Dessai and van der Sluis 2007). In Fig. 1 this approach starts at the top by assessing the vulnerability of the system and the available adaptation strategies that increase the resilience of the system. The 'assess-risk-of-policy' approach allows best for the evaluation of the robustness of possible strategies. An adaptation strategy is robust when it works good across a wide range of future scenarios (Lempert and Collins 2007). This paper reviews the use of both approaches in the Netherlands in section 6 .

\section{Knowledge Availability and Uncertainties in The Rhine Basin}

\subsection{Case Study Area: Rhine River Basin}

The river Rhine (see Fig. 3) originates in the Swiss Alps as a mountain river, fed by glacier water, snowmelt and rainfall. From Switzerland it flows through Germany, France and the Netherlands into the North Sea. Currently, the total catchment area of about $185000 \mathrm{~km}^{2}$ and the length of $1320 \mathrm{~km}$, makes the Rhine the longest river in Western Europe. In the course of time, along the Upper Rhine the discharge section has been reduced from a width of about $12 \mathrm{~km}$ to some $200-250 \mathrm{~m}$. The course of the Rhine have been shortened by $82 \mathrm{~km}$, the construction of 8 dams for hydropower and two storage dams has reduced the surface of the flood plains of the Upper Rhine area by $130 \mathrm{~km}^{2}$, which was $60 \%$ of the total retention area between Basel and Iffezheim. Today the Rhine disposes of less than $15 \%$ of the original flood plain (ICPR 2009b). The Rhine basin includes densely populated and highly industrialized areas with approximately 50 million inhabitants. The river is of great economic and environmental importance for the riparian countries. Its water is used for many sectors, such as hydropower generation, agriculture and industry and domestic water use. About 20 million people depend on Rhine water as a source of drinking water (Aerts and Droogers 2004) and it is the busiest waterway for inland navigation in Europe (Middelkoop et al. 2001). In the flood prone areas, an estimated total of about 1,500 billion Euro of property is at risk (Klein et al. 2004). Continued implementation and improvement of flood and drought prevention measures is an economic and social must. 


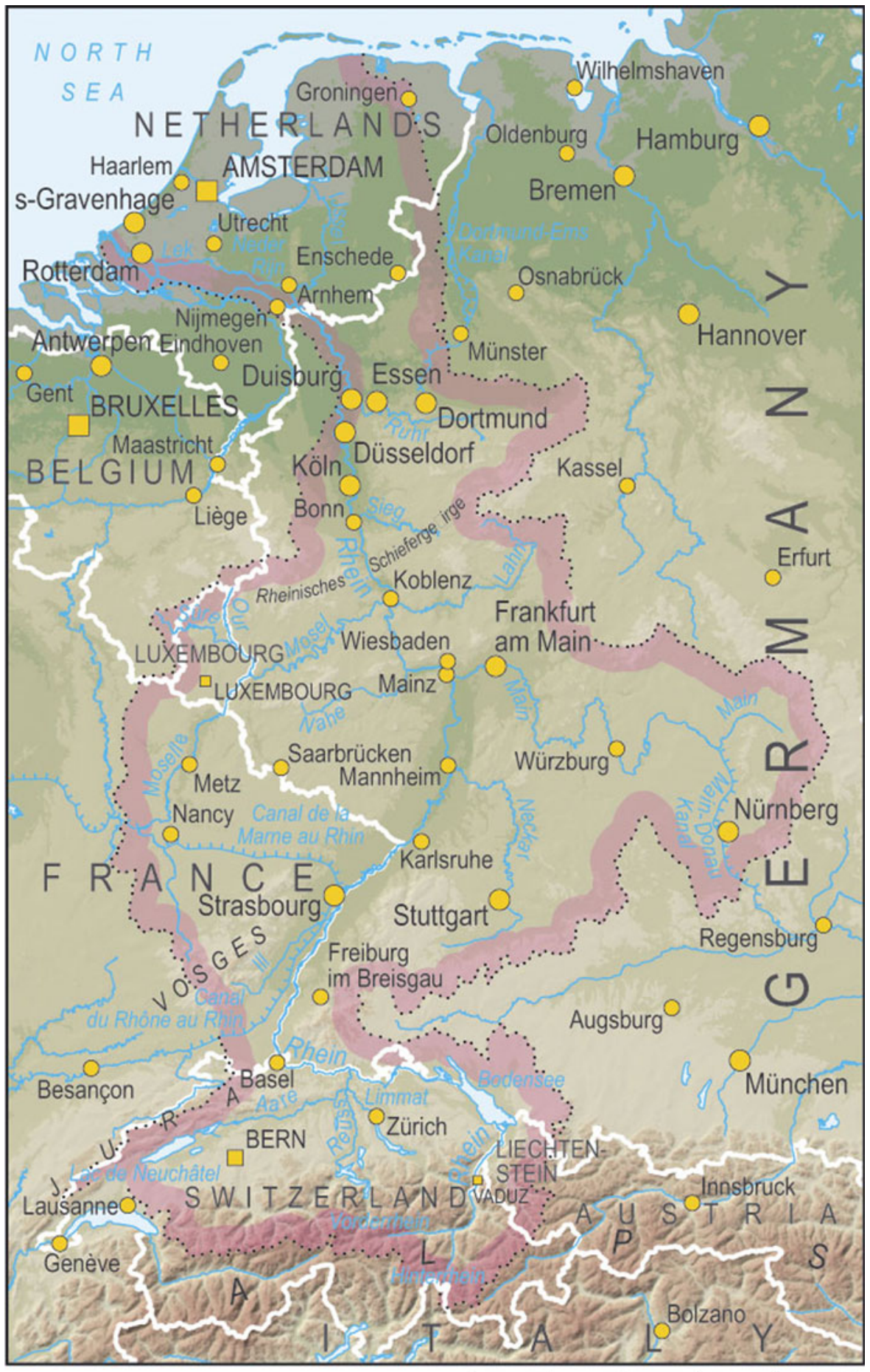

Scale 1: 6500000

Kilometres 0

50

100

150

Fig. 3 Rhine basin (source www.ecologyandsociety.org) 


\subsection{Temperature and Precipitation Projections for the Rhine Basin}

The changes in the weather system above Europe, which serve as input for hydrological models, have been analyzed in different studies. An overview by Beniston et al. (2007) presented changes in extreme events that are most likely to affect Europe in the coming decades. The results showed that the intensity of extreme temperatures increases more rapidly than the intensity of more moderate temperatures due to increases in temperature variability. The simulations showed that heavy winter precipitation is projected to increase in central and northern Europe and decrease in the south. In a high resolution simulation $(10 \mathrm{~km})$ over the Rhine basin, the regional pattern of temperature change displays a stronger warming in the south and south-east of the domain covering Germany, the Alps and Switzerland for the time period 2071-2100 compared to 1961-1990. This is associated with a decrease in precipitation in summer. An increase in winter precipitation in south and south-west regions was simulated. Less precipitation will fall in the occurrence of snow (Jacob and van den Hurk 2009). The 2006 scenarios of the Royal Dutch Meteorological Institute (KNMI) (Hurk van den 2006) project a summer decrease of the wet day frequency of up to $10-20 \%$ and an increase of wet day precipitation in the winter of $4-9 \%$ for the Netherlands. These regional changes were obtained by scaling three GCM projections with ten RCM outputs. The results above have been confirmed by a recent study of the International Commission for Protection of the Rhine (ICPR) which assessed the state of knowledge on climate change. Because of the high uncertainty in projected precipitation, the uncertainty in the impact indicators that are linked to precipitation and water supply is high (Jol et al. 2009).

\subsection{Runoff Projections for the Rhine Basin}

The potential impact of climate change on the hydrological regimes of the river Rhine has been assessed quantitatively in several studies. To estimate the impact of climate change on river discharge, different scenarios of future meteorological conditions are used as input of a hydrological model. As a scale mismatch exists between the coarse resolution of a GCM and the regional catchment scale, the GCM results have to be downscaled. This is usually done with statistical or dynamical downscaling techniques (Lenderink et al. 2007a). Both methods can generate different results adding uncertainty (Jacob and van den Hurk 2009; Lenderink et al. 2007b). For the Rhine basin different IPCC emission scenarios (Special Report on Emission Scenarios, (SRES))(Nakicenovic et al. 2000), driving GCMs and hydrological models are used. The hydrological model used most is RhineFlow (van Deursen and Kwadijk 1993). Table 1 shows that studies published on this subject show different results ranging from an average increase in discharge of $13 \%$ or even up to $30 \%$ at the end of this century. Drought projections show similar variation ranging from an average decrease in discharge of $5 \%$ to $40 \%$ in 2100 . The simulated results in these publications do have a large uncertainty range and for each study only a limited number of driving models has been used, but the results appear to agree at least in sign and order of magnitude. A detailed and meaningful comparison between the outcomes of the studies is not possible, because not only the underlying assumptions and input data are different, but also the reported output differs in terms of the choice and definition of indicators and time scales.

The overview above and Table 1 show that studies, simulating discharge for the river Rhine mostly use one or two IPCC scenarios, initially mainly the older IS92a, later the IPCC SRES A2 or A1B scenario. The IS92a and A1B scenario can be regarded as 'middle' scenarios, while A2 represents one of the highest emission scenarios (Nakicenovic et al. 2000), suggesting an intentional move from 'best guess' to 'worst case' scenario selection, 


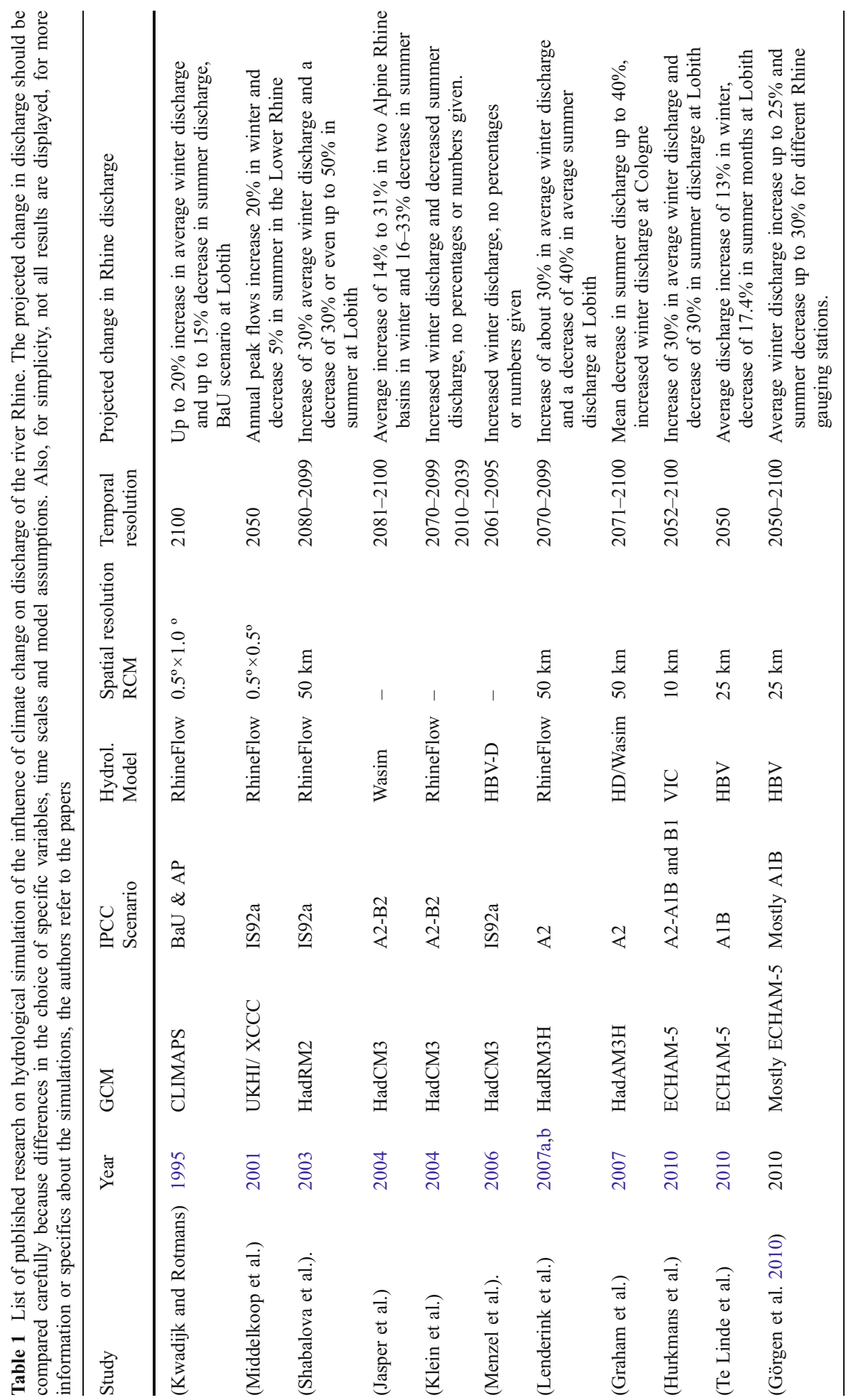


around 2005. Because the approach of these studies is different their results cannot meaningfully be compared, which makes it difficult to appreciate their relevance for policy purposes. This suggests that harmonization of definitions, methods and reported results would be highly desirable from both a scientific and policy perspective.

\subsection{Uncertainties Related to Climate Modeling and Simulated Impacts}

The uncertainties that are part of the discharge simulations for the river Rhine, result from a cascade of individual uncertainties (Giorgi 2005). The first part of this cascade consists of selecting an emission scenario, like the SRES A1B or A2 scenarios. The second part relates to the applied GCM. The choice of the driving GCM generally provides the largest source of uncertainty in downscaled scenarios (Fowler et al. 2007; Prudhomme and Davies 2009; Leander et al. 2008; Dessai 2005; Menzel et al. 2006). This means that the uncertainty range of, for example, one GCM forced by different emission scenarios is lower than that of one emission scenario forcing different GCMs. Often only 50\% of the changes predicted by GCMs can be significantly attributed to the signal of the GCM projections (Prudhomme and Davies 2009), the other changes can be, for example, attributed to natural variability. However, most studies on the impacts of climate change on the river Rhine to date only make use of one driving GCM. This indicates that a lot of uncertainty is unknown, as using multiple driving GCMs could result in significantly different outcomes (Knutti et al. 2010). The third source of uncertainty comes from the choice of downscaling technique, which could be statistical, or dynamical using RCMs. On time scales of decades, which are interesting from an adaptation point of view, uncertainties from the choice of downscaling techniques and of emission scenarios are generally smaller than uncertainty related to the choice of GCM. Sensitivity analysis using alternative climate models or scenarios are usually not reported. The reasons for this may be that hydrological modellers have resource or time constraints, or arguments which would justify the selection of a particular representative or worst case scenario, but this is not discussed in the papers that we have examined. Outputs from RCMs cannot be used in impact studies without first applying a bias correction (Fowler et al. 2007). The use of bias correction can add another level of uncertainty to the downscaling part as the used method influences the resulting discharge (van Pelt et al. 2009). The fourth source of uncertainty arises from the use of hydrological models. This part can be divided in three sources of uncertainty: random or systematic errors in the output data, uncertainty due to sub-optimal parameter values and errors due to incomplete or biased model structure (Butts et al. 2004). The final and fifth source of uncertainty is related to the observational data, that is used for bias correction, but also for validation and calibration of the hydrological model. Often observations contain measurements errors or the number of observations is too little to, for example, properly validate the model, which adds more uncertainty. These uncertainties are all examples of epistemic and stochastic uncertainty.

\subsection{Uncertainties Related to Time Scale}

Uncertainties in climate projections vary with the averaging period over which the climate is defined and with the lead time of the projection. On the time scale of a few years to a few decades ahead, regional and seasonal variation of mean temperature in the climate will be strongly influenced by natural and internal variability. This means there is less certainty about the cause of change. The human climate signal will be even harder to discern at river basin scale (Wilby et al. 2009). It is important to know the extent to which the climate 
events, like precipitation which influences river discharge, are the product of natural variability, or are the result of potentially irreversible, forced anthropogenic climate change (Hurrell et al. 2009). The changes in river discharge can also be related to non-climate factors, such as land-use changes or river basin management practices. To date, there is little knowledge about how to separate the natural and anthropogenic climate change signals for short-term forecasting. On this short time scale, uncertainties in initial conditions dominate the overall uncertainty of the projection. On longer time scales, anthropogenic emissions of greenhouse gases and aerosols, relating to scenario uncertainty, are a larger source of uncertainty than the initial conditions. A third type of uncertainty is the process and parameter uncertainty, this type increases in the first decade, but than stays relatively stable. The net effect of all these uncertainties is that the fractional uncertainty, defined as the prediction error divided by its central estimate, is smallest on the 30 to 50 year time scale (Cox and Stephenson 2007).

\section{The (mis) Match Between the Information Needs and Knowledge Availability}

Political systems are caught in four to five year democratic cycles, while future climatic impacts are calculated for time scales that are much longer. In Table 1 it is shown that most studies focus on at least the year 2050. Policymakers are more interested in changes for the next couple of years, or what these changes mean for decisions they have to make on a short timescale. This is not true for all policymakers, as there are policymakers who are not chosen every four or five years and law and legislation are designed for longer term. Despite this, earlier studies showed that climate change is generally not seen as most important in the short term (Arnell and Delaney 2006; Ivey et al. 2004). Other political priorities dominate and it is easier to make decisions on issues that have a short time span. Furthermore, the short term socio-economic factors determining adaptive capacity are at least as important for vulnerability as climatic changes. Temporal mismatches occur when the short term temporal scale of policy makers and the long term temporal scale of the climate processes do not align (Cumming et al. 2006). Furthermore, Table 1 shows that the spatial resolution of RCMs of the studies has a maximum of $50 \mathrm{~km}$. The spatial uncertainty of grid cells can be decisive for hydrological analysis of the river basin, making it difficult to make judgments on regional levels (ICPR 2009a). This also indicates that this low resolution does not always match the territorial boundaries of policymakers. The output of the hydrological model is usually a projected discharge for a specific location, like, for example, Lobith, the place where the Rhine enters the Netherlands. Local policymakers may need much more specific information. Temporal and spatial scaling complicate effective knowledge sharing between climate science and policy. This is further complicated by the fact that adding more spatial and temporal detail, often also adds more uncertainty (Alkhaled et al. 2007). Therefore, the choice of level and type of detail included in risk assessments should be driven by both scientific experts and policy makers, but this is often not the case.

Next to scaling and temporal issues, the representation of uncertainty for guiding decision-making faces a number of challenges. First, most studies quantify only a limited number of the types of uncertainties that have been mentioned in the previous section, often the total uncertainty is not clearly represented. Lack of transparency regarding the assumptions and uncertainties can lead to misunderstandings in the science-policy interface on the nature of the knowledge (Sluijs van der and von Krauss 2005). Second, the communication and representation of uncertainties is under a lot of debate. For example, the 
UK is the first country to present climate change projections for policy applications in a probabilistic framework (UKCP09) (Murphy et al. 2010). Some scientists are against this way of presenting uncertainties, as there are important limitations to our ability to project future climate conditions for adaptation decision-making (Hall 2007): uncertainties can only be quantified to a certain extent. Others find it is essential that GCM projections are accompanied by quantitative estimates of the associated probability (Giorgi 2005; Murphy et al. 2004; Wigley et al. 2003). Adding to this debate, Gawith et al. (2009) explain that the experience with UKCP09 has taught that the provision of probabilistic climate scenarios must be accompanied by ongoing guidance and support. Another lesson from UKCP was that ongoing dialogue between those providing the scenarios and the communities using them is essential. Both lessons were motivated by the experiences from the UKCP02 program, which showed that users frequently chose the Medium-High climate change scenario, because it had the most detailed information and it was seen by some as presenting a 'middle road' or a 'safe' choice. It was also less resource intensive than having to apply four scenarios (Gawith et al. 2009). This experience and debate demonstrates that there is still much to be researched in communicating climate uncertainties and that interaction between scientists and policymakers is fundamental to constructively meet the challenges associated with climate change projections. Standard methodologies to include uncertainties in potential changes and assess their impact on projected estimates have yet to be developed (Prudhomme and Davies 2009). There remains a question as to whether it is possible to develop such a generic method that will fit all situations. Until then, the debate about how to present and how to manage uncertainties can be confusing and may make it more difficult for policymakers to formulate adaptation strategies on the basis of available scientific knowledge.

\section{Transboundary Cooperation on Adaptation Management in the Rhine Basin}

\subsection{The European Level: European Union Policies}

As to the management of water in the Rhine basin, policies at all levels are relevant: EU, transnational, national and local. Up to recently, climate change impacts have not been a major concern in EU water policy (Leipprand et al. 2007). At the European level, legislation that is relevant for climate adaptation regarding the water sector are the Water Framework Directive (WFD) and the Flood Directive. The WFD requires a river basin management plan to be established for each river basin district. Although originally not explicitly included in the legislation, this management framework allows for the inclusion of climate change adaptation issues and must be updated every six years. In 2009, the Commission issued a Guidance document on how to integrate climate change into river basin management plans (EU 2009b). In 2015 the first management cycle of the WFD and the river basin management plans ends. At that time the programmes can be updated and the latest insights as to climate change impacts taken into account. The Flood Directive requires Member States to coordinate their flood risk management practices in shared river basins and to avoid taking measures that would increase the flood risk in neighbouring countries. The Directive has been published in 2007 and it requires Member States to carry out a first assessment by 2011 to identify those river basins and associated coastal areas that are at risk of flooding. The flood risk management plans should be finished by 2015 . As they only contain a limited number of explicit references to climate change impacts, these existing policy instruments can be used as a starting point but have to be developed further. 
While to date little has been done to mainstream adaptation into the relevant EU policies (Leipprand et al. 2007), recently the European Commission released a White Paper in which a framework is set out to reduce the EU's vulnerability to the impact of climate change in general (EU 2009a). It provides suggestions for a stepwise development of European adaptation policy, including the mainstreaming of adaptation into sector policies such as those related to water management. The intention is that phase 1 (2009-2012) will lay the ground work for preparing a comprehensive EU adaptation strategy to be implemented during phase 2, commencing in 2013.

\subsection{The River Basin Level: International Commission for Protection of the Rhine}

In the case of the Rhine, a river-basin-wide institution has been established, notably the International Commission for Protection of the Rhine (ICPR), a platform for the riparian countries to discuss the sustainable development of the Rhine. The ICPR was initiated in the 1950s following concerns about pollution of the river and the implications for drinking water supply. The IPCR has no formal authority to carry out measures, the decisions taken are not legally binding and implementation is the responsibility of member states (Van Ast 2000; ICPR 2009b). The Flood Action Plan, which has been established as part of the Rhine 2020 programme on sustainable development of the Rhine by the ICPR in 1998, aims to reduce risks of flooding by, for example, creating retention areas. Such measures would reduce vulnerability to climate change as well, although in 1998 there was no explicit mentioning of climate change adaptation yet. On October 18th 2007 the Conference of Rhine Ministers decided to jointly develop adaptation strategies for water management in the Rhine watershed, in order to cope with the challenges of climate change. An international expert group (KLIMA) has worked on an "analysis of the state of knowledge on climate changes so far and on the impact of climate change on the water regime in the Rhine watershed" (ICPR 2009a), but no concrete adaptation plans have been developed yet.

\subsection{The National Level: German and Dutch Adaptation Plans}

Adaptation strategies at the national level in Germany are mainly related to strategic action. The implementation of federal laws is usually delegated to the federal states (Länder) which have the primary right to develop and implement legislation in the field of water protection (Kastens and Becker 2008). The German National Adaptation Strategy (NAS) has been adopted by the Cabinet in 2008. The NAS aspires to integrate the work that is already in progress in various ministries (Swart et al. 2009). It creates a framework for adaptation to climate change, but it will require further specification. The Federal Government is therefore aiming to present an Adaptation Action Plan drawn up jointly with the Federal States by the end of March 2011. The NAS confirms the responsibility of the Länder for water safety, with the federal government playing a role in providing knowledge and tools. Regarding international cooperation the German NAS only states that the Federal Government will coordinate the German position. In the Netherlands the government has formulated a National Adaptation Strategy in 2007 called 'Make Space for Climate'. The government is currently working on a National Adaptation Agenda. The strategy documents are starting points for formulating more substantive climate adaptation policy. The document relates primarily to spatial measures, although raising awareness and identifying gaps in knowledge are also part of the strategy (Swart et al. 2009; VROM 2007). Attention for international cooperation is limited to a few sentences that indicate the importance of cooperation with other countries. How this should be managed is not 
elaborated. The Netherlands forms a delta where major European rivers flow into the North Sea, which makes the country vulnerable to flood risk. Therefore, complementary to the NAS, the Dutch government requested an independent Committee of State (the Delta Committee) to advice on flood protection and flood risk management in the Netherlands for the next century. The Delta Committee formulated twelve recommendations to secure the country against flooding on the short and medium term. The recommendations focus on this century, but the Committee's report also includes a long-term vision to 2200 (DeltaCommittee 2008). An important recommendation of this Committee is the advice to increase safety levels by a factor 10. Although in the EU White Paper transboundary or international cooperation is an important topic, in the national adaptation strategies of both the Netherlands and Germany, this seems to have little priority as yet. Contacts between scientists and policy makers in the two countries on climate change and the Rhine appear to remain limited to a few research projects of limited length, such as Rheinblick2050, some working groups of ICPR and ad-hoc meetings. At the regional level there is some cooperation between the Dutch province Gelderland and the German Land Nordrhein Westfalen. This could be an inspiration for other provinces and Länder to start cooperating more.

\subsection{Institutional and Cultural Challenges}

Adaptation actions take place within hierarchical structures; administrations at different levels interact with each other. Actions are therefore determined (facilitated or constrained) by institutional processes such as regulatory structures, property rights and social norms associated with rules in use (Adger et al. 2005). Transboundary cooperation is restrained by several differences between the Netherlands and Germany.

In Table 2 the differences between Germany and the Netherlands regarding water policy and risk perception are shown. The table is divided in three different factor categories as adopted from Dieperink (1997) and Becker et al. (2007). Safety levels, meaning the recurrence level of a design discharge in years, in the Netherlands are much higher than in Germany, see also Table 3. Both countries take a different approach in dealing with uncertainties in flood risk management. The Dutch strategy follows a more protective approach, whereas Germany puts emphasis on precaution and damage reduction (Becker et al. 2007). In the Netherlands floods are calamities with large financial and social consequences, in Germany people are more used to floods and in most areas the consequences are less severe (Steenhuisen et al. 2006). The diverse perceptions on flood risk and the corresponding safety levels can be explained by differences in potential flood impacts. In the Netherlands more than 8.5 million people live in flood risk areas, that is more than $50 \%$ of the total population. In Germany, over 2 million people live in flood risk areas, which is less than $2.5 \%$ of the total population. The financial damage in case of a flood is estimated at 130 billion euro for the Netherlands, compared to 34 billion in Germany (ICPR 2001). This estimate is based on all the properties that are located in flood risk areas. Dutch inhabitants expect higher authorities to take action regarding flood safety, in Germany floods are perceived as regional or local events against which measures have to be taken by officials as well as individuals (Becker et al. 2007). The Dutch government has adopted legal obligations concerning flood prevention and damage Compensation that are stricter than in Germany. In Germany this legislation differs between Länder (Raadgever 2005). The competence for water management in the Netherlands is primarily allocated to the national level, while in Germany the competence is allocated to the sixteen Länder, making the Länder of central importance for transboundary issues. Although the Länder 
Table 2 Differences regarding water policy and risk perception

\begin{tabular}{lll}
\hline Category & Germany & Netherlands \\
\hline Cognitive & Lower safety levels & Higher safety levels \\
& Damage reduction & Protective approach \\
& More used to floods, less financial & Large financial and social consequence \\
& and social consequence & \\
Regional and individual responsibility & National responsibility \\
Institutional & Less strict legislation & Stricter Legislation \\
& Competence located at Länder & Competence located at national level \\
Riparian position & Upstream & Downstream \\
\hline
\end{tabular}

coordinate policy and legislation concerning water management in the Länder Water Working Group (LAWA), the fact that Germany is divided in sixteen authorities makes harmonization of water management in the whole Rhine basin more difficult (Steenhuisen et al. 2006). The Rhine basin does have a history of successful international cooperation, due to the pollution of the Rhine. The quality of the water in the river has been under debate since the late 19th century and since 1950 there have been formal and informal consultations between the riparian countries. In 1960 and 1970 the pollution was so heavy that the river Rhine was called the 'sewer of Europe'. Since than, different Treaties have been established and the quality of the Rhine improved significantly. Crucial for the development of this Rhine regime has been a strong involvement of down stream parties, in combination with willing upstream parties (Dieperink 2000). International formal interactions can be a competence struggle, but due to long lasting cooperation, trust between the riparian countries has developed (Raadgever 2005). Although collaboration and information exchange on climate change has been rather ad hoc until now, experiences in the past suggest that also in the area of climate change adaptation opportunities for more structural cross-boundary collaboration in policy and science exist and can be enhanced.

\section{Dutch Case: Evolution of Design Discharge}

Important policy variables in river basin management are politically agreed safety levels and design discharges derived from scientific analyses. Safety levels refer to the frequency of flood events that is considered to be acceptable. The amount of water per second that can be associated with these safety levels and which statistically has a certain probability to occur ('design discharge') is used to design adaptation or flood protection measures, e.g. to determine the necessary height of a river dike. Both safety

Table 3 Current safety levels and design discharge for German and Dutch part of the Rhine basin

\begin{tabular}{lll} 
Part of river basin & $\begin{array}{l}\text { Safety level (recurrence } \\
\text { interval in years) }\end{array}$ & $\begin{array}{l}\text { Design discharge } \\
\left(\mathrm{m}^{3} \mathrm{~s}^{-1}\right)\end{array}$ \\
\hline Oberrhein (Germany) & $110-1000$ & $5,500-7,300$ \\
Niederrhein (Germany) & $200-500$ & $12,900-14,800$ \\
Rhinedelta (Netherlands) & $1250-10000$ & 16,000
\end{tabular}


level and design discharge differ between countries and vary over time as scientific insights and political priorities evolve.

Table 3 shows different safety levels and corresponding design discharges for Germany and the Netherlands. The safety levels in the Netherlands are up to tenfold higher than in Germany. The Dutch norms are legally binding at the national level, while the German norm can differ between Länder, depending on historic water levels and local initiatives (Steenhuisen et al. 2006).

The estimation of the probability of an extreme event, that corresponds to a high safety level is far from trivial (Te Linde et al. 2010). Safety levels for the Rhine are relatively high and with only 110 years of observed discharge data available, statistical extrapolation leads to very high uncertainties (Klemes 2000). For recent applications, more sophisticated approaches have been developed that combine weather generators with hydrological models (Buishand and Brandsma 2001), to create such long discharge series that extrapolation is redundant. However, this approach is also under debate, as it requires hydrological modelling of extreme events, far beyond available time series of historic events (Te Linde et al. 2010).

Table 4 shows the history of design discharges over the previous century and the beginning of this century. The first design discharge as we define it today was set in 1956 after the major floods of 1953 in the Netherlands. After twenty years it became clear that a design discharge of $18,000 \mathrm{~m} 3 \mathrm{~s}^{-1}$, with a safety level of $1 / 3000$ would be too costly and the measures would have a huge impact on cultural, historical and nature values. The Becht Commission, assigned by the national government, determined that the safety level could be adjusted to $1 / 1250$ and the design discharge could be decreased to $16,500 \mathrm{~m}^{3} \mathrm{~s}^{-1}$. Another twenty years later the design discharge was decreased further to $15,000 \mathrm{~m}^{3} \mathrm{~s}^{-1}$, because of a lot of public resistance against raising and broadening the dikes. This decrease in design discharge with the same safety level was consistent with a different statistical calculation method. The high waters of 1993 and 1995 placed safety back on the political agenda and the design discharge was raised again to $16,000 \mathrm{~m}^{3} \mathrm{~s}^{-1}$ in 2001 .

More extreme discharges are projected for the Rhine because of projected climate change, as explained in section 3, therefore the design discharge has been under discussion again. On the basis of a study of Middelkoop et al. (2000) the Committee Water Management 21 st century (WB21) has calculated an increase in design discharge of 5\% per degree temperature rise. If a 'middle' scenario of the Royal Dutch Meteorological Institute

Table 4 Evolution of design discharges for the Dutch part of the Rhine basin (Kwadijk et al. 2008)

\begin{tabular}{llll}
\hline Year & Design discharge $\left(\mathrm{m}^{3} \mathrm{~s}^{-1}\right)$ & $\begin{array}{l}\text { Safety level (recurrence } \\
\text { interval in years) }\end{array}$ & Event \\
\hline 1926 & Level of 1926+1 m & - & Flooding 1926 \\
1956 & 18,000 & 3000 & Flooding 1953 \\
1976 & 16,500 & 1250 & Commission Becht \\
1992 & 15,000 & 1250 & Public resistance - Commission Boertien \\
2001 & 16,000 & 1250 & Flooding and evacuation 1995 \\
$2050^{\text {a }}$ & 18,000 & 1250 & Climate change-Second Delta Committee
\end{tabular}

${ }^{a}$ It is expected that between 2050 and 2100 the design discharge should be raised to $18,000 \mathrm{~m}^{3} \mathrm{~s}^{-1}$, in 2050 the measures taken to comply with this design discharge should be finished. 
(KNMI) is taken, this translates into a design discharge of $18,000 \mathrm{~m}^{3} \mathrm{~s}^{-1}$ for the Rhine. Spatial reservations are already made for the possibility of this discharge, although other measures taken at this moment are still based on a design discharge of $16,000 \mathrm{~m}^{3} \mathrm{~s}^{-1}$. If a more extreme scenario is taken, the maximum design discharge could in theory be up to $22,000 \mathrm{~m}^{3} \mathrm{~s}^{-1}$ for 2100 . For this extreme scenario however, in practice the maximum discharge would be about $18,000 \mathrm{~m}^{3} \mathrm{~s}^{-1}$, because of flooding upstream the Rhine basin. This therefore means an upper limit of $18,000 \mathrm{~m}^{3} \mathrm{~s}^{-1}$ to the discharge that can reach the Netherlands (Kabat et al. 2009). The design discharge has been reason for a lot of discussion. The example of Table 4 illustrates the high impact of extreme events on the formulation and implementation of adaptation strategies. The determination of design discharges from statistical analyses of the measured peak discharges faces various problems. The estimation of the 1250 year discharge event from statistical information in a discharge record of about 100 years involves a strong extrapolation, which is quite uncertain. Recent developments like the development of GRADE (Generator of Rainfall And Discharge Extremes) (de Wit and Buishand 2007) have improved these extrapolations, but do not eliminate all uncertainty. The design discharge of $16,000 \mathrm{~m}^{3} \mathrm{~s}^{-1}$ was included in water safety legislation in the Netherlands in 2001, before research was done on flood safety in Germany in 2004. Without additional flood-protection measures in Germany an amount of $16,000 \mathrm{~m}^{3} \mathrm{~s}^{-1}$ would not reach the Netherlands, as the Niederrhein would flood in Germany when the discharge is between $11,000 \mathrm{~m}^{3} \mathrm{~s}^{-1}$ and $16,000 \mathrm{~m}^{3} \mathrm{~s}^{-1}$, transboundary floods would occur at $14,000 \mathrm{~m}^{3} \mathrm{~s}^{-1}$. This means that in case of large-scale flooding, the peak discharge at Lobith is reduced (Kroekenstoel and Lammersen 2005). The cooperation and communication between the Netherlands and Germany definitely could have been better, for example, it could be unnecessary for the Netherlands to take measures for extreme discharges, if Germany is not doing this.

This case is a typical example of a 'predict-then-act' approach. Science and projections are taken as a starting point and the strategy is based on these projections. The strategy is vulnerable to uncertainty and surprises, as it relies on the scientific accuracy of the projection. If the projections are not accurate and the design discharge would be estimated wrongly, the damage could be huge. This example also shows that transboundary cooperation is essential for effective river basin management. The measures taken in the Netherlands should be adapted to measures in the other riparian countries, especially Germany and vice versa.

In the Netherlands the 'assess-risk-of-policy' approach has been applied for the area of water management using the concept of "adaptation tipping points". These "tipping points" are reached if the current management strategy can no longer meet its objectives (Kwadijk et al. 2010). Only beyond the tipping points an additional adaptation strategy would be needed. The focus of this approach is on the resilience of the water system. The results of this study also have been input to the authoritative study on future adaptation options by the 2 nd Delta Committee (see section 5). A number of case studies on sea level rise in the Netherlands which have explored this approach suggest that it may better match the way policy makers address questions than the 'predict-then-act' approach. The results have shown, for example, that for dikes along the tidal river area no major technical and financial adaptation tipping points will be reached any time soon, but that potential tipping points might arise on the social- and political level. Social acceptability, for example, of living behind giant dikes may decline (Kwadijk et al. 2010).These experiences suggest that a 'assess-risk-of-policy' approach might be useful or at least complementary to the more commonly used 'predict-then-act' approach. 


\section{Discussion, Conclusions and Recommendations}

In this paper we have identified factors that facilitate or constrain effective risk management with respect to climate adaptation in transnational river basins. The Rhine river basin was taken as a case study area, as it is a large international river basin with a history of droughts and floods. Three questions were addressed in particular: 'How are climate change uncertainties dealt with?, 'How does a (mis)match between information needs and knowledge availability across different geographic and administrative scales stimulate or constrain effective adaptation policy development?', and 'What is the effect of (lack of) transboundary cooperation on adaptation management?' A number of findings emerge:

\subsection{Scientific Uncertainties Provide Opportunities for Politically Strategic Water Safety Choices}

A view on history shows that design discharges that have been established by water managers were at least informed by statistical analyses from scientific and technical advisors (see section 6). So, the demand of knowledge by policymakers appears to be matched by the supply by scientists. However, the degree to which statistical calculations determine the design discharge can be debated, as over the last century a number of times the design discharge in the Netherlands changed not only as a result of new scientific insights or statistical methods, but also as result of extreme events, financial considerations or public opposition. Extreme events increase the level of public attention and sense of urgency and design discharges were increased to ease these public concerns. After some time remembrance of extreme events seem to fade away in the minds of people and the design discharges were lowered, requiring less costly measures. The political and societal discussion that follows extreme events offers a particular window of opportunity for scientists and scientific information to play a role in policy making (Arnell and Delaney 2006). This is confirmed in a comparative study by Krysanova et al. (2010) where it was found that experts in different large river basins perceived a climate-related disaster amongst the most important drivers for development of adaptation strategies. But in turn, once the disaster is over, there is a tendency to return to the original situation instead of developing long-term policies (Christoplos 2006). While after an extreme event re-active measures are taken, climate adaptation strategies, targeting future extreme events, ought to be pro-active. This proves to be very challenging as it is more difficult to create a sense of urgency for events that have not happened yet.

\subsection{Scientific Support to Water Management Strategies Currently Inadequately Addresses Uncertainties}

Even if communication between scientists and policymakers in the area of water safety appears to have been quite satisfactory, particularly in The Netherlands, some questions can be asked. First of all, the question of selection of long-term climate scenarios is interesting. While initially a "best guess" middle scenario was used, and even incorporated in legislation, later a more "worst case" scenario was applied, although not in all cases. It is not completely clear if this was a decision by the relevant policymakers or by the scientific experts and what arguments were behind such decisions. At the same time, model calculations generally not only used one scenario, but also the output of only one global climate model, ignoring differences between model outcomes. It might be that for the coming decades the differences in terms of runoff projections between scenarios and 
climate models are relatively small and multiple model runs would be too costly, but this is not systematically discussed in the various papers and reports underpinning Dutch water policy.

In general, research on the human dimensions of climate change suggests that available information on climate change is often not perceived to be useful for policymakers, or is misused and contributes to undesired outcomes (Sarewitz and Pielke 2007). In national and regional Dutch and German adaptation strategies uncertainties are mentioned in rather general terms, but it is not explicitly explained how governments could deal with these uncertainties. As a consequence, policy makers can use uncertainties strategically, as illustrated by the evolving choices on design discharges. At the same time, scientific output in the area of water management often does not provide the policy makers with clear information about the uncertainties and how to manage them. Three mismatches between the supply of knowledge and the demand of policy makers relate to spatial and time scaling, and to the scope and form of information provided. Most climate change information is available at long-term temporal scales and large spatial scales, but most management plans or adaptation strategies, from the Water Framework Directive to national plans, have their goals set for at the latest 2015, and usually focus on smaller scales (municipalities, regions, water basins). As to scope and form: often the information provided is too complex, and not expressed in terms directly relevant for the policy question that is supposed to be addressed. Policy makers mostly need information that is simple, and relevant for short-term local decisions. Of course, this is not easy and will not solve all the climate related policy challenges, as for example, environmental policy decision making tends to be highly politicized (Castree and MacMillan 2001). Juntti et al (2009) discuss some of the challenges in the science policy interface. Firstly, they argue that the notion of validity of evidence would benefit from a more transparent treatment of the division into lay and expert knowledge in evidence generation. Secondly, the range of involved interests adds to the political struggle and finally it is argued that knowledge is only turned into 'evidence' when the political climate is ripe for a problem to be identified. Turnpenny et al. (2009) add to this discussion that technical uncertainties are often invoked as a reason for policy direction. These findings underline the arguments of this paper, the exchange of knowledge between science and policy is not straightforward and there are many factors that influence this process. For both scientists and policy makers it is important to be aware of these influences and to be clear about the choices and underlying assumptions that are made.

\subsection{Early Experiences with 'Assess-Risk-Of-Policy' Analysis of Options}

(Looking at the Climate Resilience of Development Plans Rather Than Linking

Adaptation Options to Projected Impacts) Suggest That This Method May Be Applied More Widely

Because climate change is framed as a global problem, 'predict-then-act' scenario approaches are most commonly used in developing climate adaptation strategies and measures. This approach is strong in coping with statistical uncertainties and can profit from the large amount of available impact assessments. However, projections of future climate change also have uncertainties that cannot be quantified. Too much focus on climate change scenarios alone may lead to ineffective risk management. In the Netherlands, for example, the 'predict-then-act' approach may not lead to optimal decision making in the water sector in terms of robustness, flexibility and costs, if only one scenario and one model is chosen as a best or worst case estimate (Kwadijk et al. 2010). The approach ignores governance questions. The 'assess-risk-of-policy' approach recognizes local interests and 
conditions, and offers possibilities to deal with uncertainties that cannot be quantified, by focusing on the resilience of the system. Research on this approach has only recently started, e.g. with the concept of adaptation tipping points. First results of this method show that it can offer policy makers a new, complementary tool for evaluating adaptation strategies that also addresses their non-climate priorities and maybe a different view on the urgency of adaptation to climate change. Therefore it would be interesting to do more research on 'assess-risk-of-policy' approaches and test these approaches more widely.

\subsection{Development and Implementation of Adaptation Options Derived from Integrated Analysis at the Full River Basin Level Rather Than Within the Boundaries of the Riparian Countries can Offer New Opportunities, But Will Also Meet With Many Practical Challenges}

The history of water management in the Rhine basin has shown that international cooperation can be successful. Agreements on water pollution of the Rhine have led to a successful improvement of water quality. A comparative study of Ma et al. (2008) showed that the 1998 Rhine Convention is the best transboundary water treaty for enforcement, capability and treaty implementation. This can be an example for other transboundary cooperation, e.g. to address climate change adaptation in the most cost effective manner. Taking a closer look at regional policy practices along member states' borders, however, suggests that cooperation is often still viewed as problematic. So, while 'Europe' is striving for a borderless river basin management, harsh realities reflected in regional practices do not always meet these expectations (Wiering et al. 2010). International cooperation in river basins with respect to climate change adaptation is very important, as measures in one country could have negative effects in another or country-by-country measures could be less effective or more expensive than measures optimized over the full river basin. In the case of the Rhine, the latter can be illustrated by the current understanding that the design discharge of $16,000 \mathrm{~m}^{3} \mathrm{~s}^{-1}$ was included in Dutch legislation before research was done on the impacts of floods on high water in Germany. Results of this research showed for example that an extreme discharge of $18,700 \mathrm{~m}^{3} \mathrm{~s}^{-1}$ at Lobith would be reduced to $15,500 \mathrm{~m}^{3} \mathrm{~s}^{-1}$ at Lobith because of flooding in Germany (Lammersen 2004). Of course, this may change as the climate changes and further protective measures are taken throughout the river basin. This example shows the potential importance of enhanced cooperation, especially since the projection of climate change impacts suggests that more adaptation measures will be necessary in the futureIf the difficulties caused by different institutional arrangements and cultural differences were to be explicitly recognized and systematically addressed, more effective transnational collaboration would be possible. However, to reach this goal, political will from the riparian countries is essential. Until now this will and the means to put this will into action is not clearly expressed in the governmental documents on climate adaptation that we have analyzed.

\subsection{Knowledge Gaps}

We identified a number of knowledge gaps that require research attention. While much is known about technical aspects of measures, institutional barriers for pro-active adaptation are less well understood. Research has addressed the problem of climate change uncertainties in climate and impacts models separately, but the consequences of the propagation through the various analytical steps for risk management is poorly understood. The discussion on climate-related uncertainties is mainly science-driven, and more attention 
is required on how policymakers deal with them: the communication of uncertainties should be fit for purpose. The implementation of adaptation measures depends on interactions of different governance levels - more research is required to understand how this affects the formulation and actual implementation of adaptation strategies. So far, the most common approach to impacts and adaptation assessment is the projected climate impacts-driven 'predict-then-act' approach - more attention is required to alternative, or complementary 'assess-risk-of-policy' approaches in support of the enhancement of climate resilience. Different countries in transnational river basins use different methods and climate impact information. Research to better understand the constraints and opportunities of transboundary cooperation with respect to climate change impacts and adaptation assessment in international river basins would be useful. This paper is based on literature review and informal contacts, for a better understanding of the details of how past decisions were made, more systematic research supported by well-structured interviews would be a useful complement to the literature review. While some of these suggestions are likely to be addressed in new national research programmes, such as Knowledge for Climate in the Netherlands and Klimzug in Germany, stronger and sustained international research collaboration would strengthen the scientific quality and policy-relevance of the projects.

Acknowledgements We would like to thank the following persons for taking part in meetings and interviews: Gert Bekker (IVM, VU University), Hendrik Buitenveld (RIZA), Suraje Dessai (Exeter University), Jaap Kwadijk (Deltares) and Tom Raadgever (TU Delft), The two anonymous reviewers are also acknowledged for their valuable comments, references and suggestions.

Open Access This article is distributed under the terms of the Creative Commons Attribution Noncommercial License which permits any noncommercial use, distribution, and reproduction in any medium, provided the original author(s) and source are credited.

\section{References}

Adger N, Arnell N, Tompkins E (2005) Successful adaptation to climate change across scales. Global Environ Change 15(2):77-86

Aerts J, Droogers P (2004) Climate change in contrasting river basins: adaptation strategies for water, food and environment. CABI.

Aerts J, Droogers P (2009) Adapting to climate change in the water sector. Climate change adaptation in the water sector:87.

Alkhaled A, Michalak A, Bulkley (2007) J Applications of Risk Assessment in the Development of Climate Change Adaptation Policy. In: American Society of Civil Engineers, 1801 Alexander Bell Drive, Reston, VA, 20191-4400, USA.

Arnell N, Delaney E (2006) Adapting to climate change: public water supply in England and Wales. Clim Change 78(2):227-255

Becker G, Aerts J, Huitema D (2007) Transboundary flood management in the Rhine basin: challenges for improved cooperation. Water science and technology: a journal of the International Association on Water Pollution Research 56(4):125

Beniston M, Stephenson D, Christensen OB, Ferro CAT, Frei C, Goyette S, Halsnaes K, Holt T, Jylhä K, Koffi B (2007) Future extreme events in European climate: an exploration of regional climate model projections. Clim Change 81:71-95

Buishand TA, Brandsma T (2001) Multisite simulation of daily precipitation and temperature in the Rhine Basin by nearest-neighbor resampling. Water Resour Res 37(11):2761-2776. doi:10.1029/2001wr000291

Butts MB, Payne JT, Kristensen M, Madsen H (2004) An evaluation of the impact of model structure on hydrological modelling uncertainty for streamflow simulation. J Hydrol 298(1-4):242-266

Castree N, MacMillan T (2001) Dissolving dualisms: actor-networks and the reimagination of nature. Social nature: theory, practice, and politics:208-224. 
Christoplos I (2006) The elusive "Window of Opportunity" for risk reduction in post disaster recovery. In: pp. 2-3.

Cox P, Stephenson D (2007) Climate change: a changing climate for prediction. Science 317(5835):207. doi:10.1126/science. 1145956

Cumming G, Cumming D, Redman C (2006) Scale mismatches in social-ecological systems: causes, consequences, and solutions. Ecol Soc 11(1):14

DeltaCommittee (2008) Delta Committee Report, Final Report and interim Advice.

Dessai S (2005) Robust adaptation decisions amid climate change uncertainties. University of East Anglia,

Dessai S, Hulme M (2003) Does climate policy need probabilities. Tyndall centre for climate change research working paper $34: 40$

Dessai S, Hulme M (2004) Does climate adaptation policy need probabilities. Clim Pol 4(2):107-128

Dessai S, van der Sluis J (2007) Uncertainty and climate change adaptation-scoping study Copernicus Institute University of Utrecht, Tyndall Centre for Climate Research, School of Environmental Sciences University of East Anglia.

Dessai S, Hulme M, Lempert R, Pielke R Jr (2009) Do we need better predictions to adapt to a changing climate. Eos Trans AGU 90:13

Dieperink C (1997) International regime development: lessons from the Rhine catchment area. TDRI Q Rev 12(3):27-35

Dieperink C (2000) Successful international cooperation in the Rhine catchment area. Water Int 25(3):347-355

de Wit M, Buishand A (2007) Generator of Rainfall And Discharge Extremes (GRADE) for the Rhine and Meuse basins. Rijkswaterstaat KNMI, Lelystad

EU (2009a) WHITE PAPER Adapting to climate change: towards a European framework for action. Brussel.

EU (2009b) Common implementation strategy for the Water Framework Directive. River basin management in a changing climate. European Commission Guidance Document No.24.

Fink A, Brücher T, Krüger A, Leckebusch G, Pinto J, Ulbrich U (2004) The 2003 European summer heatwaves and drought-synoptic diagnosis and impacts. Weather 59(8):209-216

Fowler H, Blenkinsop S, Tebaldi C (2007) Linking climate change modelling to impacts studies: recent advances in downscaling techniques for hydrological modelling. Int J Climatol 27(12):1547-1578

Gawith M, Street R, Westaway R, Steynor A (2009) Application of the UKCIP02 climate change scenarios: Reflections and lessons learnt. Global Environ Change 19(1):113-121

Giorgi F (2005) Climate change prediction. Clim Change 73(3):239-265

Görgen K, Beersma J, Brahmer G, Buiteveld H, Carambia M, Keizer de O, Krahe P, Nilson E, Lammersen R, Perrin C, Volken D (2010) Assessment of Climate Change Impacts on Discharge in the Rhine River Basin: Results of the RheinBlick2050 Project CHR Lelystad.

Graham L, Hagemann S, Jaun S, Beniston M (2007) On interpreting hydrological change from regional climate models. Clim Change 81:97-122

Hall J (2007) Probabilistic climate scenarios may misrepresent uncertainty and lead to bad adaptation decisions. Hydrol Process 21(8)

Hurkmans R, Terink W, Uijlenhoet R, Torfs P, Jacob D, Troch PA (2010) Changes in streamflow dynamics in the Rhine basin under three high-resolution regional climate scenarios. J Clim 23(3):679-699. doi: doi:10.1175/2009JCLI3066.1

Hurk van den B (2006) KNMI climate change scenarios 2006 for the Netherlands. Ministerie van Verkeer en Waterstaat, Koninklijk Nederlands Meteorologisch Instituut (KNMI).

Hurrell J, Delworth T, Danabasoglu G, Drange H, Griffies S, Holbrook N, Kirtman B, Keenlyside N, Latif M, Marotzke J (2009) Decadal Climate Prediction: Opportunities and Challenges. Ocean Obs 9.

ICPR (2001) Rhein Atlas 2001. International Commission for Protection of the Rhine,

ICPR (2009a) Analysis of the state of knowledge on climate changes so far and on the impact of climate change on the water regime in the Rhine watershed. International Commission for the Protection of the Rhine (IPCR), Koblenz.

ICPR (2009b) International Commission for the Protection of the Rhine. http://www.iksr.org/. Accessed 01-09 2009.

IPCC (2007) Climate change 2007: Synthesis Report. IPCC, Valencia, Spain.

Ivey J, Smithers J, de Loe R, Kreutzwiser R (2004) Community capacity for adaptation to climate-induced water shortages: linking institutional complexity and local actors. Environ Manage 33(1):36-47

Jacob D, van den Hurk B (2009) Climate change scenarios at the global and local scales. Climate Change Adaptation in the Water Sector:23.

Jasper K, Calanca P, Gyalistras D, Fuhrer J (2004) Differential impacts of climate change on the hydrology of two alpine river basins. Clim Res 26:113-129

Jol A, Raes F, Menne B (2009) Impacts of Europe's changing climate-2008 indicator based assessment. Institute of Physics Publishing, p 292042 
Juntti M, Russel D, Turnpenny J (2009) Evidence, politics and power in public policy for the environment. Environ Sci Pol 12(3):207-215

Kabat P, Fresco L, Stive M, Veerman C, van Alphen J, Parmet B, Hazeleger W, Katsman C (2009) Dutch coasts in transition. Nat Geosci 2(7):450-452

Kandlikar M, Risbey J, Dessai S (2005) Representing and communicating deep uncertainty in climate-change assessments. Compt Rendus Geosci 337(4):443-455

Kastens B, Becker G (2008) Consequences of European governance structures and institutions for the regional scale - the example of adaptive water management in the Lower Rhine region. "Not published yet".

Klein H, Douben K, van Deursen W, van Steveninck E (2004) Water, climate, food, and environment in the Rhine basin. Contribution to the project ADAPT, Adaptation strategies to changing environments, p. 58.

Klemes V (2000) Tall tales about tails of hydrological distributions. I. J Hydrol Eng 5(3):227-231

Knutti R, Furrer R, Tebaldi C, Cermak J, Meehl GA (2010) Challenges in combining projections from multiple climate models. J Clim 23(10):2739-2758. doi:10.1175/2009JCLI3361.1

Kroekenstoel D, Lammersen R (2005) Transboundary effects of extreme floods on the Lower Rhine. NCR-days 2004.

Krysanova V, Dickens C, Timmerman J, Varela-Ortega C, Schlüter M, Roest K, Huntjens P, Jaspers F, Buiteveld H, Moreno E (2010) Cross-comparison of climate change adaptation strategies across large river basins in Europe, Africa and Asia. Water Resources Management:1-40.

Kwadijk J, Rotmans J (1995) The impact of climate change on the river Rhine: a scenario study. Clim Change 30(4):397-425

Kwadijk J, Jeuken A, van Waveren H (2008) De klimaatbestendigheid van Nederland Waterland: Verkenning van knikpunten in beheer en beleid voor het hoofdwatersysteem. Rijkswaterstaat, Deltares.

Kwadijk JCJ, Haasnoot M, Mulder JPM, Hoogvliet MMC, Jeuken ABM, van der Krogt RAA, van Oostrom NGC, Schelfhout HA, van Velzen EH, van Waveren H, de Wit MJM (2010) Using adaptation tipping points to prepare for climate change and sea level rise: a case study in the Netherlands. Wiley Interdisciplinary Reviews: Climate Change 1(5):729-740. doi:10.1002/wcc.64

Lammersen R (2004) Grensoverschrijdende effecten van extreem hoogwater op de Niederrhein. Duits-Nederlandse Werkgroep Hoogwater.

Leander R, Buishand T, van den Hurk B, de Wit M (2008) Estimated changes in flood quantiles of the river Meuse from resampling of regional climate model output. J Hydrol 351(3-4):331-343

Lehner B, Döll P, Alcamo J, Henrichs T, Kaspar F (2006) Estimating the impact of global change on flood and drought risks in Europe: a continental, integrated analysis. Clim Change 75(3):273-299

Leipprand A, Dworak T, Benzie M, Berglund M, Hattermann F, Krysanova V, Post J, Kadner S (2007) Impacts of climate change on water resources-adaptation strategies for Europe. Pik, Ecologic.

Lempert RJ, Collins MT (2007) Managing the risk of uncertain threshold responses: comparison of robust, optimum, and precautionary approaches. Risk Anal 27(4):1009-1026

Lempert R, Nakicenovic N, Sarewitz D, Schlesinger M (2004) Characterizing climate-change uncertainties for decision-makers. An editorial essay. Clim Change 65(1):1-9

Lempert R, Groves D, Popper S, Bankes S (2006) A general analytic method for generating robust strategies and narrative scenarios. Management Science Vol 52 (No. 4).

Lenderink G, Buishand A, van Deursen W (2007a) Estimates of future discharges of the river Rhine using two scenario methodologies: direct versus delta approach. Hydrol Earth Syst Sci 11(3):1145-1159

Lenderink G, Van Ulden A, Van den Hurk B, Keller F (2007b) A study on combining global and regional climate model results for generating climate scenarios of temperature and precipitation for the Netherlands. Clim Dynam 29(2):157-176

Lopez A, Fung F, New M, Watts G, Weston A, Wilby RL (2009) From climate model ensembles to climate change impacts and adaptation: a case study of water resource management in the southwest of England. Water Resour Res 45(8):W08419. doi:10.1029/2008wr007499

Ma J, Hipel K, De M, Cai J (2008) Transboundary water policies: assessment, comparison and enhancement. Water Resour Manag 22(8):1069-1087

Marks G, Hooghe L (2004) Contrasting visions of multi-level governance. Multi-level governance:15-30.

Menzel L, Thieken A, Schwandt D, Bürger G (2006) Impact of climate change on the regional hydrologyscenario-based modelling studies in the German Rhine catchment. Nat Hazards 38(1):45-61

Middelkoop H, Daamen K, Gellens D, Grabs W, Kwadijk J, Lang H, Parmet B, Schädler B, Schulla J, Wilke K (2001) Impact of climate change on hydrological regimes and water resources management in the Rhine basin. Clim Change 49(1):105-128

Middelkoop H, Rotmans J, van Asselt MBA, Kwadijk JCJ, van Deursen WPA (2000) Development of perspective-based scenarios for global change assessment for water management in the lower Rhine delta. UNESCO-WOTRO International Working Conference, "Water for Society", IHE-Delft 
Milly P, Betancourt J, Falkenmark M, Hirsch R, Kundzewicz Z, Lettenmaier D, Stouffer R (2008) Stationarity is dead: whither water management? Earth 4:20

Murphy J, Sexton D, Barnett D, Jones G, Webb M, Collins M, Stainforth D (2004) Quantification of modelling uncertainties in a large ensemble of climate change simulations. Nature 430(7001):768-772

Murphy J, Sexton D, Jenkins G, Boorman P, Booth B, Brown K, Clark R, Collins M, Harris G, Kendon E (2010) Climate change projections for the UK (UKCP09), p. 06.

Nakicenovic N, Alcamo J, Davis G, de Vries B, Fenhann J, Gaffin S, Gregory K, Grubler A, Jung T, Kram T (2000) Special report on emissions scenarios: a special report of Working Group III of the Intergovernmental Panel on Climate Change. Pacific Northwest National Laboratory, Richland, WA (US), Environmental Molecular Sciences Laboratory (US).

Palmer M, Lettenmaier D, Poff N, Postel S, Richter B, Warner R (2009) Climate change and river ecosystems: protection and adaptation options. Environ Manage 44(6):1053-1068. doi:10.1007/s00267-009-9329-1

Patt A (2009) Communicating uncertainty to policy makers. Uncertainties in Environmental Modelling and Consequences for Policy Making:231.

Pielke R Jr, Sarewitz D, Byerly R Jr (2000) Decision making and the future of nature: understanding and using predictions. Prediction: science, decision making, and the future of nature Island Press, Washington, DC:361-387.

Pierre J (2000) Debating governance. Oxford University Press, USA

Prudhomme C, Davies H (2009) Assessing uncertainties in climate change impact analyses on the river flow regimes in the UK. Part 2: future climate. Clim Change 93(1):197-222

Raadgever G (2005) Transboundary river basin management regimes: The Rhine basin case study. Background report to Deliverable 1.3.1 of the NeWater project. Delft University of Technology, Delft.

Sadoff C, Grey D (2002) Beyond the river: the benefits of cooperation on international rivers. Water Pol 4 (5):389-403

Sarewitz D, Pielke R (2007) The neglected heart of science policy: reconciling supply of and demand for science. Environ Sci Pol 10(1):5-16

Schär C, Vidale P, Lüthi D, Frei C, Häberli C, Liniger M, Appenzeller C (2004) The role of increasing temperature variability in European summer heatwaves. Nature 427(6972):332-336

Shabalova M, van Deursen W, Buishand T (2003) Assessing future discharge of the river Rhine using regional climate model integrations and a hydrological model. Clim Res 23(3):233-246

Sluijs van der J, von Krauss K (2005) Uncertainty as a monster in the science-policy interface: four coping strategies. vol 52. IWA Publishing, Alliance House 12 Caxton Street London SW 1 H 0 QS UK.

Steenhuisen B, Dicke W, Tijink D (2006) Veiligheid verwaterd? Een narratieve analyse van Nederlands en Duits hoogwaterbeleid. Bestuurswetenschappen 60(3)

Swart R, Biesbroek R, Binnerup S, Carter T, Cowan C, Henrichs T, Loquen S, Mela H, Morecroft M, Reese M, Rey D (2009) Europe adapts to climate change: comparing national adaptation strategies. Partnership for European Environmental Research (PEER), Helsinki.

Te Linde AH, Aerts JCJH, Bakker AMR, Kwadijk JCJ (2010) Simulating low-probability peak discharges for the Rhine basin using resampled climate modeling data. Water Resour Res 46(3):W03512. doi:10.1029/ 2009wr007707

Turnpenny J, Lorenzoni I, Jones M (2009) Noisy and definitely not normal: responding to wicked issues in the environment, energy and health. Environ Sci Pol 12(3):347-358

Van Ast J (2000) Interactief watermanagement in grensoverschrijdende riviersystemen. Eburon, Delft

van Deursen W, Kwadijk J (1993) RHINEFLOW: an integrated GIS water balance model for the river Rhine. In: Kovar K, Nachtnebel H (eds) Vienna Conference, Vienna. HydroGIS 93: Application of Geographic Information Systems in Hydrology and Water Resources. IAHS Press, pp 507-519.

van Pelt S, Kabat P, Ter Maat H, van den Hurk B, Weerts A (2009) Discharge simulations performed with a hydrological model using bias corrected regional climate model input. Hydrol Earth Syst Sci Discuss 6 (3):4589-4618

VROM (2007) National Programme on Climate Adaptation and Spatial Planning-National adaptation strategy policy memorandum.

Wiering M, Verwijmeren J, Lulofs K, Feld C (2010) Experiences in regional cross border co-operation in river management. Comparing three cases at the Dutch-German Border. Water Resour Manag 24 (11):2647-2672. doi:10.1007/s11269-009-9572-5

Wigley T, Caldeira K, Hoffert M, Sanger B, Schlesinger M, Schneider S, Trenberth K (2003) Climate research. Issues in Science and Technology (Spring 2003).

Wilby RL, Dessai S (2010) Robust adaptation to climate change. Weather 65(7):180-185. doi:10.1002/wea.543

Wilby R, Troni J, Biot Y, Tedd L, Hewitson B, Smith D, Sutton R (2009) A review of climate risk information for adaptation and development planning. Int J Climatol. 